\title{
Penerapan Entrepreneural Marketing Pada Kelompok Usaha Ekonomi Kreatif(Creativepreneur) di Desa Pakis Dalam Upaya Penguatan Desa Pakis Sebagai Desa Sejahtera Mandiri (DSM)
}

\author{
Honest Dody Molasy, Illia Seldon Magfiroh, Intan Kartika Setyawati \\ Universitas Jember \\ Honestdody.fisip@unej.ac.id
}

\begin{abstract}
Abstrak
Universitas Jember memiliki kontribusi yang cukup besar dalam mengupayakan pengentasan kemiskinan di Desa Pakis. Bekerjasama dengan Kementerian Sosial Republik Indonesia, Universitas Jember telah menetapkan Desa Pakis sebagai Desa binaan yang mendapatkan program Desa Sejahtera Mandiri (DSM). Salah satu upaya yang bisa dilakukan untuk mengentaskan kemiskinan dan menciptakan kemandirian desa adalah dengan mendirikan Kelompok Usaha Ekonomi Kreatif (Creativepreneur). Tujuan pengabdian ini adalah Melakukan pendampingan dan edukasi kepada mitra Kelompok Ekonomi Kreatif Desa Pakis mengenai (a) pemasaran produk dengan menerapkan Entrepreneural Marketing, (b) pengolahan produk berbasis potensi pertanian lokal dan pembuatan kerajinan tangan berbasis limbah produk, (c) strategi pengembangan bisnis dan analisis usaha, (d) manajemen organisasi usaha dan masyarakat. Kegiatan pengabdian PPK mulai dilaksanakan pada bulan Oktober tahun 2018 sampai dengan awal Desember 2018. Metode pelaksanaan dilakukan melalui tahapan (1) identifikasi permasalahan mitra, (2) sosialisasi kegiatan, (3) edukasi Entrepreneural Marketing, (4) pelatihan pembuatan kerajinan tangan, (5) pelatihan produk olahan berbasis potensi local, (6) edukasi analisis usaha, strategi pengembangan usaha serta manajemen organisasi dan masyarakat. Hasil pengabdian menunjukkan bahwa kegiatan pengabdian PPK memberikan dampak positif bagi mitra. Indikatornya terlihat pada adanya perubahan pemikiran dan sikap terkait dengan manajemen dan pengembangan usaha, antara lain Meningkatnya pengetahuan dan ketrampilan untuk dapat lebih kreatif dalam memasarkan produk sehingga dapat meningkatkan pendapatan mitra yang nantinya akan menjadi mitra yang mandiri, Meningkatnya pengetahuan dan pemahaman tentang Entrepreneural Marketing, Meningkatnya ketrampilan dan kreatifitas usaha dibidang kerajinan tangan dan pengolahan produk makanan berbasis potensi pertanian lokal, Meningkatnya kemampuan menyusun analisis usaha dan menetapkan strategi pengembangan usaha, dan Meningkatnya kesadaran pentingnya manajemen organisasi dan masyarakat.
\end{abstract}

Kata Kunci: Entrepreneural Marketing, Creativepreneur, Desa Pakis, Desa Sejahtera Mandiri

\footnotetext{
Abstract

Jember University has a significant contribution in the efforts to alleviate poverty. In collaboration with the Ministry of Social Affairs of the Republic of Indonesia, Jember University has promoted Desa Pakis as a guided village that receives the Mandiri Prosperous Village (DSM) program. One effort that can be done to alleviate poverty and create village independence is to establish a Creative Economy Business Group (Creativepreneur). The
} 
purpose of this service is to provide assistance and education to the Desa Creative Group on (a) product marketing by implementing Entrepreneurial Marketing, (b) processing products based on local agricultural potential and making handicraft products based on waste products, (c) business development strategies and business analysis, (d) management of business and community organizations. KDP service activities will begin in October 2018 until early December 2018. The implementation method is carried out through stages (1) identification of partner problems, (2) socialization of activities, (3) Entrepreneurial Marketing education, (4) handicraft making training, (5) training for processed products based on local potential, (6) education on business analysis, business development strategies and organizational and community management. The results of dedication show that KDP service activities have a positive impact on partners. The indicators can be seen in the change of mind and attitude related to management and business development, among others increasing knowledge and skills to be more creative in marketing products so as to increase the income of partners who will later become independent partners, Increased knowledge and understanding of Entrepreneurial Marketing, Increased business skills and creativity in the field of handicraft and food product processing based on local agricultural potential, increased ability to compile business analysis and establish business development strategies, and increased awareness of the importance of organizational and community management

Kata Kunci: Entrepreneural Marketing, Creativepreneur, Desa Pakis, Desa Sejahtera Mandiri

\section{PENDAHULUAN}

Universitas Jember memiliki kontribusi yang cukup besar dalam mengupayakan pengentasan kemiskinan di Desa Pakis. Desa Pakis merupakan sebuah desa yang terletak di daerah Jember bagian Utara. Lokasi Desa Pakis yang termasuk jauh dari kota dan lebih dekat dengan kawasan pegunungan membuat mata pencaharian utama penduduk desa Pakis sebagian besar adalah petani, buruh perkebunan dan peternak, namun ada beberapa warga yang berprofesi sebagai PNS dan Pegawai swasta. Sebagian besar mata pencaharian masyarakat Desa Pakis yang masih bergantung pada alam serta tingkat pendidikan yang relatif rendah mengakibatkan pendapatan yang dihasilkan oleh warga juga terbatas. Kondisi ini berimplikasi pada tingginya jumlah penduduk miskin di Desa Pakis, dan rendahnya IPM (Indeks Pembangunan Manusia). Berdasarkan data Bappeda Jember, Desa Pakis berada di bawah rata-rata IPM Kabupaten Jember. Jumlah prosentase penduduk miskin juga tergolong sangat tinggi. Dari jumlah penduduk Desa Pakis sebesar 5.819 jiwa, 4432 orang tercatat sebagai penduduk miskin. Angka ini berarti 76,16 $\%$ penduduk Desa Pakis tergolong penduduk miskin.

Upaya untuk mengentaskan kemiskinan dan meningkatkan IPM di Desa Pakis sebenarnya sudah dilakukan sejak lama. Universitas Jember memiliki kontribusi yang cukup besar dalam mengupayakan pengentasan kemiskinan di Desa Pakis. Bekerjasama dengan Kementerian Sosial Republik Indonesia, Universitas Jember telah menetapkan Desa Pakis sebagai Desa binaan yang mendapatkan program Desa Sejahtera Mandiri (DSM) yang diimplementasikan 
dalam KKN tematik DSM sejak tahun 2016. Salah satu upaya yang bisa dilakukan untuk mengentaskan kemiskinan dan menciptakan kemandirian desa adalah dengan mendirikan Kelompok Usaha Ekonomi Kreatif (Creativepreneur).

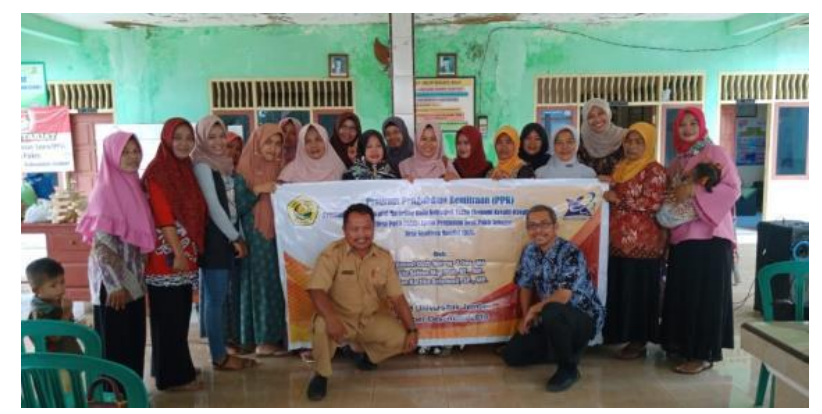

Gambar 1. Kelompok PKK Desa Pakis

Ibu rumah tangga yang tergabung dalam kelompok PKK di Desa Pakis berinisiatif untuk mendirikan kelompok usaha ekonomi kreatif dengan tujuan utama yaitu meningkatkan kesejahteraan keluarga terutama dan masyarakat pada umumnya. Sebagai usaha yang baru berdiri permasalahan utama yang dihadapi yaitu (a) Belum adanya pemasaran produk baru yang efektif dan efisien, (b) Kurangnya pengetahuan mitra mengenai pembuatan produk olahan berbasis potensi pertanian lokal, (c) Kurangnya pengetahuan mitra mengenai strategi pengembangan bisnis dan analisis usaha sebagai creativepreneur yang baru dan (d) Kurangnya pengetahuan mitra mengenai manajemen organisasi masyarakat.

Entrepreneurial Marketing dapat dikatakan kegiatan pemasaran yang dilakukan oleh usaha baru dan usaha kecil.Stokes (dalam Hamali, 2013), konsep entrepreneurial marketing difokuskan pada inovasi dan pengembangan ide-ide sesuai dengan perkembangan pasar. Pemasaran secara luas dianggap sebagai kunci untuk kelangsungan hidup, pengembangan dan keberhasilan usaha kecil atau baru. Konsep ini sangatlah sesuai untuk diterapkan pada usaha kelompok ekonomi kreatif di Desa Pakis, karena usaha ini termasuk usaha baru yang butuh kreativitas dan inovasi.

Kegiatan pembinaan dan eduksi mengenai Entrepreneural Marketing sebaiknya didefiniskan dulu secara singkat konsep ini, merupakan upaya yang dilakukan oleh Tim Pengabdian PPK untuk mengatasi permasalahan pertama dari mitra yaitu pemasaran produk. Ibu-ibu PKK yang tergabung dalam kelompok usaha kreatif sangat bersemangat selama kegiatan berlangsung. Hal ini membuktikan bahwa peserta mitra memiliki kemauan yang kuat untuk memperbaiki usahanya. Tim Pengabdian PPK menyampaikan materi tentang pentingnya pemasaran dalam sebuah usaha terutama usaha yang baru dirintis. Pemasaran merupakan ujung tombak dari suatu usaha, tanpa adanya pemasaran yang baik maka produk yang dihasilkan juga tidak akan dapat sampai pada konsumen. Istilah entrepreneurial 
dapat diartikan sebagai orientasi strategi yang mempengaruhi fungsi organisasi pemasaran.

Bjerke dan Hutltman (2006), menyatakan entrepreneurial marketing dalam usaha kecil mentargetkan organisasi atau individu yang memiliki efek positif atau negatif terhadap produk, harga, promosi dan saluran distribusi versus marketing interaktif. Melalui kata sifat "entrepreneurship" menggambarkan sebuah pendekatan kepada marketing yang mencakup opportunities dari marketplace dengan sebuah implementasi yang efektif dari price, place, promotion, dan product tactics (4P) dengan berani mengambil resiko, inovatif, dan proaktif dengan menekankan pada kegiatan paling penting entrepreneurial marketing yaitu berkaitan dengan promosi.

Apabila dikaitkan dengan produk yang dihasilkan oleh ibu-ibu PKK yang tergabung dalam kelompok usaha kreatif Desa Pakis penerapan entrepreneurial marketing dapat dilakukan dengan pendekatan strategi 4P. P yang pertama yaitu product, produk yang dihasilkan oleh kelompok usaha kreatif harus lebih menonjolkan keunikan produk dan memberikan tampilan dalam bentuk kemasan yang menarik. Kemasan yang menarik seperti label dengan nama merk yang lebih simpel dan mudah diingat konsumen dapat menjadi salah satu daya tarik produk.

Pengembangan produk seperti memproduksi produk lain yang tidak sejenis juga dapat menjadi alternatif pemasukan serta dapat membagi risiko usaha. Selanjutnya yaitu strategi harga, penentuan harga dapat dilakukan sesuai dengan target konsumen dan jumlah minimum pembelian produk. Strategi berikutnya yaitu Place, tempat disini dapat diartikan sebagai saluran distribusi produk atau tempat dimana produk dipasarkan. Produk kelompok usaha kreatif Desa Pakis dapat di pasarkan secara online dan off line, untuk pemasaran online dapat mendaftar pada market place yang terpercaya. Pemasaran off line dilakukan dengan mendistribusikan produk pada toko kerajinan atau toko oleh-oleh di Jember.

Promosi atau strategi yang ketiga dilakukan secara online melalui sosial media seperti instagram, facebook, whatsapp dan lain sebagainya. Promosi secara online dirasa lebih efektif dikarenakan dapat menembus pasar yang cukup luas serta dapat mengatasi kekurangan jauhnya Desa Pakis dari pusat kota atau target konsumen. Tim Pengabdian PPK telah membantu mitra dengan mendaftarkan pada market place dan sosial media sebagai media pemasaran secara online serta memberikan pembinaan dan edukasi tentang bagaimana trik melakukan pemasaran secara online. Mitra juga dapat memanfaatkan website Desa Pakis untuk mempromosikan produk. Kelemahan dari kegiatan ini yaitu sulitnya mendapatkan sinyal internet di daerah tempat tinggal mitra sehingga pembinaan dan eduksi mengenai pemasaran secara online hanya dapat dilaksanakan pada Balai Desa Pakis dikarenakan terdapat wifi yang dipasang pada tempat tersebut. 


\section{PELATIHAN PEMBUATAN KERAJINAN TANGAN}

Pelatihan pembuatan kerajinan tangan berupa pelatihan pembuatan hiasan dinding melibatkan semua anggota tim pengabdian, mahasiswa dan tim dari Jember Craft Community. Pilihan bentuk pelatihan kerajinan tangan berupa hiasan dinding bertujuan (a) Memberikan alternatif bisnis kerajinan tangan yang beragam. Diketahui bahwa beberapa kelompok usaha di Desa Pakis banyak berbisnis menghasilkan produk kerajinan tangan berupa tas, (b) Memberikan informasi adanya kecenderungan perubahan dan perkembangan selera pasar atau konsumen yang cenderung bergerak dinamis dan cepat, terbukti kerajinan tangan saat ini yang diminati oleh konsumen adalah bukan kerajinan tas melainkan kerajinan tangan berupa hiasan dinding, (c) Mendekatkan para pengusaha atau pengrajin di desa pakis dengan comunitas kerajinan tangan di Jember dalam hal ini Jember Craft Community (JCC) sebagai upaya kami agar kelompok pengrajin desa pakis dapat memperluas jaringan usaha, dapat terjalin kerja sama dan kemitraan yang berkelanjutan sekaligus mempererat jalinan usaha serta memperluas pasar.
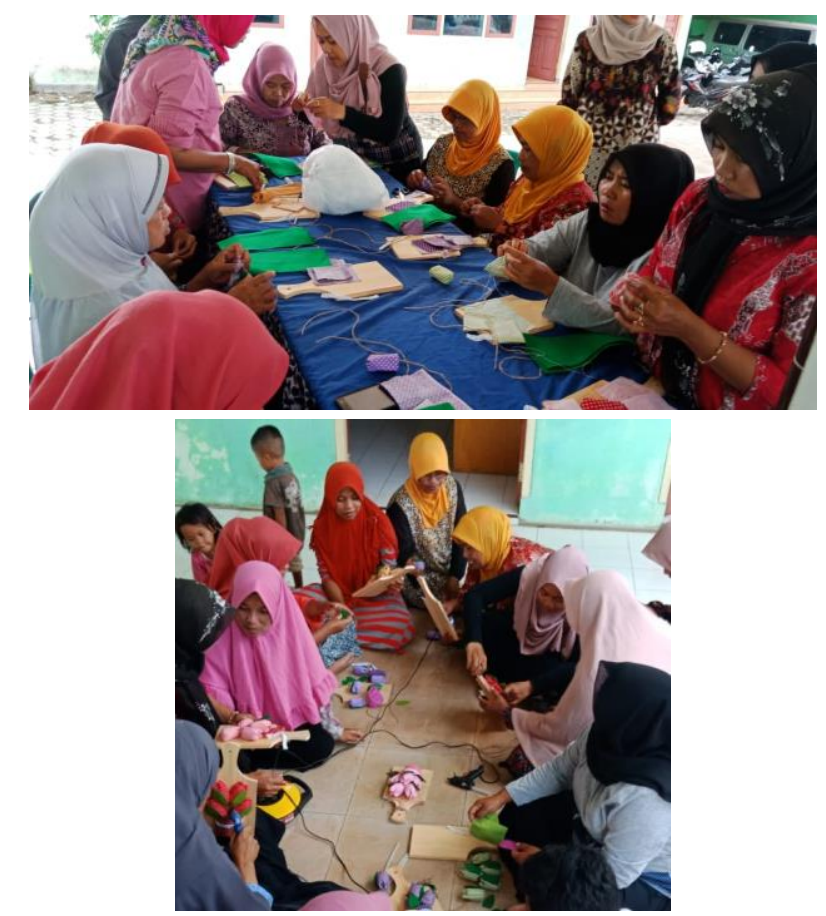

Gambar 2. Proses Pembuatan Kerajinan Tangan

Pelatihan berlangsung dengan lancar dan dihadiri oleh kurang lebih 30 orang. Pada saat pelatihan, nampak partisipasi aktif dan antusiasme yang tinggi dari peserta. Masing-masing peserta mendapatkan 1 paket bahan pelatihan dan wajib menyelesaikan kerajinan hiasan sampai berhasil. Kendala terbesar yang dihadapi adalah masih ada sebagian kecil peserta yang kurang terampil dan kurang fokus dikarenakan dalam kondisi tidak sehat. Namun demikian, secara keseluruhan, semua peserta berhasil membuat kerajinan tangan berupa hiasan dinding. 


\section{PELATIHAN PRODUK OLAHAN BERBASIS POTENSI PERTANIAN LOKAL}

Kegiatan Pelatihan produk olahan berbasis potensi pertanian lokal ini sebagai solusi yang ditawarkan pada permasalahan mitra tentang kurangnya inovasi dalam pengembangan produk. Pelatihan ini juga sejalan dengan strategi pemasaran produk yang diharapkan mitra tidak hanya fokus pada satu jenis produk saja sehingga dapat membagi risiko usaha ke dalam beberapa bagian. Pelaksanaan kegiatan berjalan dengan lancar yang dihadiri oleh kurang lebih 30 orang ibu-ibu PKK di Balai Desa Pakis. Ibu-ibu PKK terlihat sangat antusias selama mengikuti kegiatan ini sebab ibu-ibu PKK bisa lagsung praktek dan berinteraksi dengan Tim Pengabdian ketika terdapat hal yang ditanyakan.

Tim Pengabdian PPK memberikan pelatihan olahan berbasis pertanian lokal yaitu produk stik jamur. Jamur yang digunakan yaitu jamur tiram yang dapat dibudidayakan dimanapun termasuk di Desa Pakis. Pembuatan stik jamur menggunakan dua rasa yaitu rasa bawang dan rasa asin. Pemilihan dua rasa ini merupakan bagian dari strategi produk untuk menambah pilihan bagi konsumen. Ibu-ibu PKK dibagi menjadi dua kelompok untuk dapat mempraktekkan pembuatan stik jamur dua rasa tersebut. Pelatihan pembuatan stik jamur tidak hanya pada proses peoduksi saja akan tetapi sampai pada cara pengemasan dan labelling. Ibu-ibu PKK juga diberikan pelatihan bagaimana cara mengemas dengan baik dan benar. Karena kemasan merupakan hal yang pentig bagi produk selain untuk menjaga kualitas produk kemasan juga berfungsi sebagai media promosi melalui label. Kemasaan merupakan wajah pertama yang dilihat oleh konsumen sebelum konsumen memutuskan untuk melakukan pembelian. Rangkaian kegiatan berjalan dengan lancar serta mendapatkan respon positif dari mitra serta tidak terdapat kendala yang berarti.

\section{ANALISIS USAHA DAN STRATEGI PENGEMBANGAN USAHA}

Pembinaan tahap berikutnya adalah Pembinaan dan edukasi mengenai analisis usaha dan strategi pengembangan usaha. Pengetahuan dan kemampuan analisis usaha berkaitan dengan kemampuan pengusaha untuk melakukan evaluasi terhadap perkembangan usahanya. Pelatihan ini diberikan dikarenakan sebagian besar pelaku usaha di desa pakis belum melakukan analisis usaha dan bagaimana strategi pengembangan usaha sangat bermanfaat bagi kemajuan dan keberlanjutan usaha. Kegiatan ini dihadiri oleh 30 orang yang tergabung dalam unit usaha PKK desa Pakis. Pelatihan berlangsung dengan lancar. Partisipasi dan keterlibatan peserta bagus. Namun demikian, masih diperlukan pembinaan dan pendampingan lanjutan dikarenakan beberapa peserta baru mengenal kegiatan analisis usaha. Adapun bentuk pelatihan analisis usaha meliputi (a) menghitung pendapatan, 
laba dan rugi, (b) Break Even Point (BEP) serta (c) Menghitung Harga Pokok Penjualan.

\section{MANAJEMEN ORGANISASI DAN MASYARAKAT}

Pembinaan dan edukasi mengenai manajemen organisasi dan masyarakat sangat diperlukan bagi masyarakat yang tergabung dalam kelompok usaha bersama di bawah naungan PKK. Belum terciptanya manajemen organisasi yang cukup baik menjadi salah satu pemicu kenapa kelompok usaha bersama di desa Pakis tidak dapat berjalan dengan baik. Dengan memahami fungsi organisasi dan pengelolaan organisasi yang benar, maka dipastikan aka nada kejelasan ekspektasi kerja, menghindari overlapping kerja-tugas, mengetahui arus aktivitas kerja, menentukan saluran2 komunikasi dan mekanisme koordinasi. Kegiatan ini dihadiri oleh 30 orang yang tergabung dalam unit usaha PKK desa Pakis. Pelatihan berlangsung dengan lancar. Partisipasi dan keterlibatan peserta bagus. Kegiatan ini dihadiri oleh 30 orang yang tergabung dalam unit usaha PKK desa Pakis. Pelatihan berlangsung dengan lancar. Partisipasi dan keterlibatan peserta bagus.

\section{Kesimpulan}

\section{PENUTUP}

Kegiatan pengabdian PPK memberikan dampak positif bagi mitra. Indikatornya terlihat pada adanya perubahan pemikiran dan sikap terkait dengan manajemen dan pengembangan usaha. Perubahan pemikiran dan sikap ditunjukkan oleh mitra melalui indikator berikut ini :

a. Meningkatnya pengetahuan dan ketrampilan untuk dapat lebih kreatif dalam memasarkan produk sehingga dapat meningkatkan pendapatan mitra yang nantinya akan menjadi mitra yang mandiri

b. Meningkatnya pengetahuan dan pemahaman tentang Entrepreneural Marketing

c. Meningkatnya ketrampilan dan kreatifitas usaha dibidang kerajinan tangan dan pengolahan produk makanan berbasis potensi pertanian lokal

d. Meningkatnya kemampuan menyusun analisis usaha dan menetapkan strategi pengembangan usaha

e. Meningkatnya kesadaran pentingnya manajemen organisasi dan masyarakat

\section{Saran}

Keberhasilan pelaksanaan kegiatan pengabdian PPK di Desa Pakis Kecamatan Panti tidak terlepas dari kesadaran pelaku usaha yang tergabung dalam organisasi PKK desa Pakis dan dukungan yang besar dari Bapak Kepala Desa beserta staf desa. Oleh karena itu, dukungan dan keberpihakan aparat desa sangat diperlukan dalam 
bentuk pembinaan, pemberdayaan dan pendampingan melalui peningkatan peluang kerja sama dan kemitraan secara terus menerus baik dengan institusi pemerintahan yang lebih tinggi, Perguruan Tinggi dalam hal ini Universitas Jember mengingat Desa Pakis merupakan salah satu desa binaan UNEJ, media massa baik lokal maupun nasional, serta dukungan dari community-community bisnis yang sesuai demi kemajuan dan keberlanjutan usaha kreatif di Desa Pakis Kecamatan Panti.

\section{DAFTAR PUSTAKA}

Anonim (2018). Entrepreneural Marketing. https://library.binus.ac.id/eColls/eThesisdoc/Bab2/2015-1-00157MN\%20Bab200l.pdf. Diakses Tanggal 1 Desember 2018.

Kamil, Ridwan. 2016. "Creativepreneur by Ridwan Kamil". https://putricarmelita.wordpress.com/creativity-and innovation/creativepreneur-by-ridwan-kamil/. Diakses tanggal 20 Oktober jam 20.15 WIB

Syafi'i, Imam. 2014. Desa Pakis Kecamatan Panti Kabupaten Jember. http://watuleterku.blogspot.co.id/2014/03/desa-pakis-kecamatan-pantikabupaten.html. Diakses tanggal 16 Oktober 2018.

Todaro, Michael dan Smith, Stephen. 2004. Pembangunan Ekonomi. Erlangga. Jakarta

https://library.binus.ac.id/eColls/eThesisdoc/Bab2/2015-1-00157MN\%20Bab2001.pdf 